\title{
Ellagic Acid and Zinc Aspartate Ameliorate Gamma Radiation Induced Biochemical Alterations in Male Rats
}

O. S. Ali, A. S. Nada*, D. M. Abd El-lateif and M. H. Mekkawy*\#

Biochemistry Dept., Faculty of Pharmacy (Girls), Al Azhar University. ${ }^{*}$ Drug Radiation Research Dept., National Centre for Radiation Research and Technology (NCRRT), P. O. Box: 29 Nasr City, Cairo, Egypt. E-mail: maimekkawy@hotmail.com

\begin{abstract}
7 HIS STUDY was designed to investigate the protective effect of oral administration of ellagic acid (EA), a natural polyphenol $(50 \mathrm{mg} / \mathrm{kg}$ body $\mathrm{wt})$ and/or zinc aspartate (ZA) $(50 \mathrm{mg} / \mathrm{kg}$ body wt) against the cellular damage induced by whole body gamma irradiation (6.5Gy as a single dose) in male albino rats. The results of the current study revealed that exposure to $\gamma$-radiation exhibited a potential elevation of serum iron, total iron binding capacity (TIBC) and transferrin; as well as lipid peroxidation (LPO) and metallothioneins (MTs) in liver and kidney. In addition, there were significant decrease in superoxide dismutase (SOD) and reduced glutathione (GSH). In addition, tissues of liver and kidney displayed changes in some trace elements concentrations. Rats treated with EA and/or ZA before and after whole body $\gamma$-irradiation revealed significant modulation of the biochemical parameters and improvement in the antioxidant status, which might be effective in minimizing the radiation-induced increase in LPO as well as changes in essential trace elements in liver and kidney tissues reflecting a synergistic effect.

Keywords: Ellagic acid, zinc aspartate, $\gamma$-radiation, rats.
\end{abstract}

All living organisms are continuously, exposed to background ionizing radiation coming from natural sources or manmade ionizing radiation (Kaczmarska et al., 2011). Radiation therapy is considered one of the most popular and important tools to cure cancer but the radio sensitivity of normal tissues away from the tumour sites are suggested to limit the therapeutic gain (Agrawal et al., 2001). It is well known that high doses of ionizing radiation result in overproduction of oxygen-derived free radicals, which cause peroxidation of membrane proteins and lipids; further products of peroxidation are mutagenic and 
carcinogenic (Lowenthal and Airey, 1997). Biological effects of these highly reactive compounds are controlled in vivo by a wide spectrum of antioxidant mechanisms (Guney et al., 2004).

There is growing interest in understanding the role and mechanism of the phytochemicals. Among all phytochemicals, EA acid is a naturally occurring polyphenol compound; it has been receiving the most attention because of its wide array of biological properties, such as radical scavenging, chemo preventive, anticancer, antiviral and antibacterial properties (Özkaya et al., 2010). It is mostly abundant in berries, walnuts, pecans, mango kernel, pomegranate and grapes (Wang et al., 2009).

Zinc is an essential trace element with its catalytic and structural role in many enzymes (Maret, 2006). It also plays an essential role in cell viability due to its antioxidant, anti-apoptotic, anti-inflammatory effects, and it acts as a growth cofactor, an important immune regulator, and a cyto-protector (Ozkaya et al., 2011). ZA was found to be more effective than GSH and cysteine as a remarkable radio protector (Sorenson, 2002). The focus of this study was to evaluate the radio protective effect of EA and/or ZA.

\section{Material and Methods}

\section{Maintenance of animals}

Adult male albino rats (120-150g) were obtained from Ucmma Company for Chemical Industry, Cairo, Egypt, were kept for 7 days for laboratory acclimatization and fed on commercial pellets and provided with tap water. All animal procedures are in accordance with the general guidelines of animal care and recommendations of the Canadian Committee for Care and Use of Animals (Canadian Council of Animal Care, 1993). All efforts were made to minimize the number of animals used and their suffering.

\section{Irradiation}

Whole body gamma-irradiation was carried out using a Canadian ${ }^{137}$ Cesium source, Gamma Cell-40 biological irradiator, located at the NCRRT, Egypt. It is characterized by a uniform distribution of rays for small biological materials with no external hazards for the operating persons. Rats were exposed to a single dose level of $6.5 \mathrm{~Gy}$ with a dose rate of $0.42 \mathrm{~Gy} / \mathrm{min}$.

Egypt. J. Rad. Sci. Applic., Vol. 26, No. 1-2 (2013) 


\section{Treatments}

EA; 97\% was purchased from Sigma-Aldrich Co. (St Louis, Mo, USA). It was dissolved in corn oil and administered at a dose of $(50 \mathrm{mg} / \mathrm{kg}$ body $\mathrm{wt})$, orally (p.o.) by gavagesaccording to Pari and Sivasankari (2008).

ZA was purchased from Atos Pharma, Cairo, Egypt. It was dissolved in distilled water and supplied p.o. by gavages to rats at a dose of $(50 \mathrm{mg} / \mathrm{kg}$ body wt) equivalent to $10 \mathrm{mg}$ elemental zinc according to Turut et al. (2009).The animals were categorized into eight groups $(\mathrm{n}=8)$. Group 1: control (nontreated\& non-irradiated). Group 2: exposed to $\gamma$-radiation. Group 3: received EA. Group 4: $\gamma$-irradiation+ EA. Group 5: received ZA. Group 6: $\gamma$-irradiation+ ZA. Group 7: EA+ ZA. Group 8: $\gamma$-irradiation+ EA+ ZA. EA and ZA were supplied to the irradiated groups for 21 days before irradiation and 7 days after irradiation as triple dose per week. At the end of the experimental period of 28 days, the rats were subjected to diethyl ether anaesthesia then, sacrificed. Serum and tissue samples (liver \& kidney) were collected.

\section{Biochemical analysis}

Serum iron was determined according to Dreux (1977), TIBC was determined according to Piccardi et al. (1972) and transferrin was calculated theoretically from TIBC according to Tsung et al. (1975). In liver and kidney tissues; SOD activity was determined according to Minami and Yoshikawa (1979), LPO products were estimated as TBARS using the method of Yoshioka et al. (1979), GSH content was estimated according to Ellman (1959) and MTs were determined by Ag-saturation hemolysate method according to Onosaka and Cherian (1982). The biochemical assay was achieved using Herios UV/VIS Spectrophotometers, Japan. Trace elements were measured by using Atomic Absorption Spectrometer, SOLAR System Unicam 939, England, after digestion of tissues in nitric acid and $\mathrm{H}_{2} \mathrm{O}_{2}(5: 1)$ by using microwave digestor MLS-1200 Mega, Italy (Kingston and Jassei, 1988).

\section{Statistical analysis}

Analysis of data was performed using one-way analysis of variance (ANOVA) followed by Tukey-Kramer test using Prism Dimo-4 program. Results were expressed as mean \pm S.E. Value of $P<0.05$ was considered statistically significant.

Egypt. J. Rad. Sci. Applic., Vol. 26, No. 1-2 (2013) 


\section{Results}

Results in Table 1. revealed that, $\gamma$-irradiation led to a significant increase in serum iron, TIBC and transferrin compared to control group. Administration of EA before and after $\gamma$-irradiation returned serum iron to the normal range. Administration of ZA alone pre \& post irradiation significantly reduced serum TIBC \& transferrin; while together with EA revealed significant reduction in serum iron, TIBC and transferring compared with the irradiated group.

TABLE 1. Effect of ellagic acid and/ or zinc aspartate on serum iron, TIBC and transferrin.

\begin{tabular}{|c|c|c|c|}
\hline Groups & $\begin{array}{c}\text { Iron } \\
(\mu \mathrm{g} / \mathrm{dl})\end{array}$ & $\begin{array}{c}\text { TIBC } \\
(\mu \mathrm{mol} / \mathrm{l})\end{array}$ & $\begin{array}{c}\text { Transferrin } \\
(\mathrm{g} / \mathrm{l})\end{array}$ \\
\hline Control & $103.0 \pm 8.5$ & $219.0 \pm 21.0$ & $8.7 \pm 0.8$ \\
\hline IRR & $175.0 \pm 15.0^{\mathrm{a}}$ & $508.0 \pm 42.0^{\mathrm{a}}$ & $20.2 \pm 1.7^{\mathrm{a}}$ \\
\hline EA & $104.3 \pm 7.0$ & $227.3 \pm 15.0$ & $8.9 \pm 0.6$ \\
\hline EA+ IRR & $148.2 \pm 7.0$ & $499.5 \pm 29.0^{\mathrm{a}}$ & $19.9 \pm 1.2^{\mathrm{a}}$ \\
\hline ZA & $119.4 \pm 11.0$ & $248.5 \pm 8.2$ & $9.9 \pm 0.3$ \\
\hline ZA+ IRR & $132.8 \pm 13.0$ & $341.0 \pm 29.0^{\mathrm{b}}$ & $13.6 \pm 1.2^{\mathrm{b}}$ \\
\hline EA+ZA & $115.5 \pm 6.0$ & $221.4 \pm 12.2$ & $8.8 \pm 0.5$ \\
\hline EA+ZA+ IRR & $116.8 \pm 8.9^{\mathrm{b}}$ & $327.0 \pm 11.0^{\mathrm{b}}$ & $13 \pm 0.4^{\mathrm{b}}$ \\
\hline
\end{tabular}

${ }^{(a)}$ Significant difference from control at $P<0.05 .{ }^{(b)}$ Significant difference from irradiated group at $P<0.05$. Each group represent 8 animals, mean \pm S.E.

Table 2. showed that $\gamma$-irradiation caused a significant decrease of liver SOD and GSH and a significant increase in MTs and LPO when compared to control group. Supplementation of rats with EA to non-irradiated animals induced significant drop of GSH when compared with control group, while EA administration pre \& post exposure to $\gamma$-radiation showed a significant elevation in hepatic GSH and a decrease in LPO and MTs compared to the irradiated group. ZA administration before and after exposure to $\gamma$-radiation showed a significant elevation in SOD and GSH and a significant drop in LPO. Coadministration of EA and ZA pre \& post irradiation showed significant differences compared to the irradiated group in all oxidative stress parameters. Table 3. revealed that $\gamma$-irradiation resulted in a significant decrease in SOD and GSH of kidney and a significant increase in LPO and MTs as compared to control group. Supplementation of rats with EA before and after exposure to $\gamma$-radiation showed a significant drop in LPO. ZA administration to nonirradiated animals significantly elevated liver and kidney GSH when compared with control group, while ZA pre \& post $\gamma$-irradiation exhibited a significant

Egypt. J. Rad. Sci. Applic., Vol. 26, No. 1-2 (2013) 
drop in LPO \& MTs and significant elevation in SOD \& GSH when compared to irradiated group. Both treatments with irradiation dropped LPO and MTs and elevated SOD significantly compared to irradiated group.

TABLE 2. Effect of ellagic acid and/ or zinc aspartate on some liveroxidative stress biomarkers.

\begin{tabular}{|c|c|c|c|c|}
\hline Groups & $\begin{array}{c}\text { SOD } \\
(\mathrm{U} / \mathrm{ml})\end{array}$ & $\begin{array}{c}\text { LPO } \\
(\mathrm{nmol} / \mathrm{mg})\end{array}$ & $\begin{array}{c}\text { GSH } \\
(\mathrm{mg} / \mathrm{g} \text { tissue })\end{array}$ & $\begin{array}{c}\text { MTs } \\
(\mathrm{mg} / \mathrm{g} \text { tissue })\end{array}$ \\
\hline Control & $58 \pm 1.7$ & $63.5 \pm 2.7$ & $62.0 \pm 2.9$ & $27.5 \pm 1.0$ \\
\hline IRR & $28 \pm 2.0^{\mathrm{a}}$ & $168.0 \pm 10.7^{\mathrm{a}}$ & $14.0 \pm 0.8^{\mathrm{a}}$ & $40.5 \pm 2.4^{\mathrm{a}}$ \\
\hline EA & $53 \pm 2.5$ & $76.1 \pm 2.3$ & $49.0 \pm 0.3^{\mathrm{a}}$ & $22.0 \pm 1.9$ \\
\hline EA+ IRR & $37 \pm 2.9^{\mathrm{a}}$ & $137.0 \pm 10.0^{\mathrm{a}, \mathrm{b}}$ & $29.4 \pm 1.6^{\mathrm{a}, \mathrm{b}}$ & $30.3 \pm 2.0^{\mathrm{b}}$ \\
\hline ZA & $65 \pm 2.3$ & $60.0 \pm 2.6$ & $88.9 \pm 2.2^{\mathrm{a}}$ & $34.3 \pm 2.9$ \\
\hline ZA+ IRR & $52 \pm 3.3^{\mathrm{b}}$ & $106.0 \pm 7.0^{\mathrm{a}, \mathrm{b}}$ & $39.0 \pm 1.1^{\mathrm{a}, \mathrm{b}}$ & $44.8 \pm 4.0^{\mathrm{a}}$ \\
\hline EA+ ZA & $59 \pm 4.5$ & $41.0 \pm 4.0$ & $91.0 \pm 3.2^{\mathrm{a}}$ & $31.0 \pm 3.0$ \\
\hline EA+ ZA+ IRR & $48 \pm 3.0^{\mathrm{b}}$ & $138.0 \pm 5.3^{\mathrm{a}, \mathrm{b}}$ & $41.0 \pm 3.4^{\mathrm{a}, \mathrm{b}}$ & $20.4 \pm 1.5^{\mathrm{b}}$ \\
\hline
\end{tabular}

Legends are as in Table 1.

TABLE 3. Effect of ellagic acid and/ or zinc aspartate on some kidney oxidative stress biomarkers.

\begin{tabular}{|c|c|c|c|c|}
\hline Groups & $\begin{array}{c}\text { SOD } \\
(\mathrm{U} / \mathrm{ml})\end{array}$ & $\begin{array}{c}\text { LPO } \\
(\mathrm{nmol} / \mathrm{mg})\end{array}$ & $\begin{array}{c}\text { GSH } \\
(\mathrm{mg} / \mathrm{g} \text { tissue })\end{array}$ & $\begin{array}{c}\text { MTs } \\
(\mathrm{mg} / \mathrm{g} \text { tissue })\end{array}$ \\
\hline Control & $48.6 \pm 1.5$ & $138 \pm 6.0$ & $42.0 \pm 3.0$ & $9.0 \pm 0.5$ \\
\hline IRR & $33.4 \pm 1.4^{\mathrm{a}}$ & $289 \pm 11.5^{\mathrm{a}}$ & $13 \pm 1.1^{\mathrm{a}}$ & $17.0 \pm 1.6^{\mathrm{a}}$ \\
\hline EA & $52.0 \pm 1.9$ & $152 \pm 1.5$ & $33 \pm 2.9$ & $8.2 \pm 0.8$ \\
\hline EA+ IRR & $36.0 \pm 1.9^{\mathrm{a}}$ & $224 \pm 14.0^{\mathrm{a}, \mathrm{b}}$ & $16 \pm 1.6^{\mathrm{a}}$ & $15.0 \pm 1.3$ \\
\hline ZA & $55.7 \pm 3.0$ & $159 \pm 3.6$ & $93 \pm 1.6^{\mathrm{a}}$ & $12.5 \pm 1.2$ \\
\hline ZA+ IRR & $54.8 \pm 4.0^{\mathrm{b}}$ & $216 \pm 15.0^{\mathrm{a}, \mathrm{b}}$ & $32 \pm 2.8^{\mathrm{a}, \mathrm{b}}$ & $14.0 \pm 1.2^{\mathrm{b}}$ \\
\hline EA+ ZA & $60.0 \pm 3.0$ & $143.2 \pm 5.6$ & $89 \pm 3.3^{\mathrm{b}}$ & $7.4 \pm 0.5$ \\
\hline EA+ ZA+ IRR & $53.7 \pm 1.0^{\mathrm{b}}$ & $233 \pm 18.0^{\mathrm{a}, \mathrm{b}}$ & $19 \pm 0.5^{\mathrm{a}}$ & $9.1 \pm 0.8^{\mathrm{b}}$ \\
\hline
\end{tabular}

Legends are as in Table 1.

Table 4. revealed that whole body $\gamma$-irradiation caused a significant decrease in the liver $\mathrm{Zn}, \mathrm{Mg} \& \mathrm{Mn}$ levels and a significant increase in Fe \& Ca levels compared with the control group. Supplementation of non-irradiated rats with EA induced significant elevation of liver Fe when compared with control group, while EA administration before and after exposure to $\gamma$-radiation could significantly elevate $\mathrm{Zn}$ and Mn levels, Whereas supplementation of rats with ZA pre and post exposure to $\gamma$-radiation significantly elevated $\mathrm{Zn}$ and $\mathrm{Mg}$ levels compared to irradiated group. While co-administration of EA and ZA to the irradiated rats showed significant difference in $\mathrm{Zn}, \mathrm{Fe}$ and $\mathrm{Mg}$ compared to irradiated group.

Egypt. J. Rad. Sci. Applic., Vol. 26, No. 1-2 (2013) 
TABLE 4. Effect of ellagic acid and/ or zinc aspartate on some liver trace elements content.

\begin{tabular}{|c|c|c|c|c|c|}
\hline Groups & $\begin{array}{c}\mathbf{Z n} \\
(\mathrm{mg} / \mathrm{g})\end{array}$ & $\begin{array}{c}\mathbf{F e} \\
(\mathrm{mg} / \mathrm{g})\end{array}$ & $\begin{array}{c}\mathbf{C a} \\
(\mathrm{mg} / \mathrm{g})\end{array}$ & $\begin{array}{c}\mathbf{M g} \\
(\mathrm{mg} / \mathrm{g})\end{array}$ & $\begin{array}{c}\mathbf{M n} \\
(\mathrm{mg} / \mathrm{g})\end{array}$ \\
\hline Control & $32.6 \pm 1.1$ & $176.2 \pm 6.0$ & $92.4 \pm 4.0$ & $448.0 \pm 12.0$ & $1.4 \pm 0.08$ \\
\hline IRR & $23.3 \pm 0.2^{\mathrm{a}}$ & $307.0 \pm 16.0^{\mathrm{a}}$ & $124.0 \pm 5.4^{\mathrm{a}}$ & $404.0 \pm 4^{\mathrm{a}}$ & $1.0 \pm 0.06^{\mathrm{a}}$ \\
\hline EA & $28.6 \pm 1.5$ & $265.0 \pm 7.2^{\mathrm{a}}$ & $118.5 \pm 9.7$ & $453.0 \pm 6.8$ & $1.8 \pm 0.10^{\mathrm{a}}$ \\
\hline EA+ IRR & $32.3 \pm 1.5^{\mathrm{b}}$ & $311.0 \pm 1.4^{\mathrm{a}}$ & $131.0 \pm 6.5^{\mathrm{a}}$ & $417.0 \pm 8.0$ & $1.6 \pm 0.10^{\mathrm{b}}$ \\
\hline ZA & $28.7 \pm 1.8$ & $283.6 \pm 8.4^{\mathrm{b}}$ & $125.0 \pm 8.0$ & $452.0 \pm 14.0$ & $1.5 \pm 0.09$ \\
\hline ZA+ IRR & $28.3 \pm 1.7^{\mathrm{b}}$ & $267.0 \pm 20.0^{\mathrm{a}}$ & $126.0 \pm 11^{\mathrm{a}}$ & $439.0 \pm 9.3^{\mathrm{b}}$ & $1.2 \pm 0.10$ \\
\hline EA+ ZA & $32.0 \pm 2.8$ & $267.0 \pm 11.0^{\mathrm{b}}$ & $118.4 \pm 6.0$ & $428.0 \pm 5.3$ & $1.4 \pm 0.10$ \\
\hline EA+ ZA+ IRR & $31.0 \pm 1.1^{\mathrm{b}}$ & $254.0 \pm 5.6^{\mathrm{a}, \mathrm{b}}$ & $120.6 \pm 5.0$ & $437.0 \pm 11^{\mathrm{b}}$ & $1.3 \pm 0.10$ \\
\hline
\end{tabular}

Legends are as in Table 1.

Comparinged with the control group, Table 5. illustrated that whole body $\gamma$-irradiation caused significant increase in the kidney $\mathrm{Ca} \& \mathrm{Mn}$ concentrations, while EA and/or ZA showed non-significant effect in all estimated elements in the kidney tissues. Administration of EA and/or ZA pre and post irradiation caused a significant drop of kidney $\mathrm{Ca}$ while both treatments with irradiation dropped $\mathrm{Ca} \& \mathrm{Mn}$ concentration compared to irradiated group.

TABLE 5. Effect of EA and/ or ZA on some kidney trace elements content.

\begin{tabular}{|c|c|c|c|c|c|}
\hline Groups & $\begin{array}{c}\mathbf{Z n} \\
(\mathrm{mg} / \mathrm{g})\end{array}$ & $\begin{array}{c}\text { Fe } \\
(\mathrm{mg} / \mathrm{g})\end{array}$ & $\begin{array}{c}\text { Ca } \\
(\mathrm{mg} / \mathrm{g})\end{array}$ & $\begin{array}{c}\mathbf{M g} \\
(\mathrm{mg} / \mathrm{g})\end{array}$ & $\begin{array}{c}\mathbf{M n} \\
(\mathrm{mg} / \mathrm{g})\end{array}$ \\
\hline Control & $22.7 \pm 0.6$ & $292 \pm 11$ & $215.5 \pm 14.5$ & $372.7 \pm 18.6$ & $1.3 \pm 0.08$ \\
\hline IRR & $21.0 \pm 0.5$ & $286 \pm 22$ & $293.4 \pm 17^{\mathrm{a}}$ & $421.0 \pm 20.4$ & $2.2 \pm 0.20^{\mathrm{a}}$ \\
\hline EA & $20.0 \pm 0.7$ & $316 \pm 28$ & $211.0 \pm 13.5$ & $394.0 \pm 30.4$ & $1.5 \pm 0.10$ \\
\hline EA+ IRR & $22.8 \pm 0.6$ & $271 \pm 20$ & $226.0 \pm 8.0^{\mathrm{b}}$ & $391.0 \pm 26.3$ & $2.0 \pm 0.20^{\mathrm{a}}$ \\
\hline ZA & $21.5 \pm 1.1$ & $305 \pm 26$ & $202.0 \pm 17.0$ & $398.0 \pm 17.8$ & $1.8 \pm 0.18$ \\
\hline ZA+ IRR & $21.6 \pm 1.7$ & $275 \pm 20$ & $224.4 \pm 17^{\mathrm{b}}$ & $332.0 \pm 15.5$ & $1.6 \pm 0.10$ \\
\hline EA+ ZA & $20.7 \pm 0.9$ & $248 \pm 14$ & $223.0 \pm 11.4$ & $364.0 \pm 15.0$ & $1.8 \pm 0.10$ \\
\hline EA+ ZA+ IRR & $21.0 \pm 1.0$ & $258 \pm 10$ & $237.0 \pm 18.0^{\mathrm{b}}$ & $368.0 \pm 30.0$ & $1.5 \pm 0.09^{\mathrm{b}}$ \\
\hline
\end{tabular}

Legends are as in Table 1.

\section{Discussion}

In the current study-irradiation caused an elevation in the level of serum iron, TIBC and transferrin from the control group. Maiti et al. (2001) explained the elevation in transferrin after $\gamma$-irradiation by the incensement of its mRNA levels. However the elevated serum iron might be a compensatory response to provide iron to irradiation-damaged tissues or it might also be due to radiation

Egypt. J. Rad. Sci. Applic., Vol. 26, No. 1-2 (2013) 
induced changes in erythrocyte membrane which might contributed to the eventual leakage of haemoglobin out of the cells and release of iron from ferritin (Nassar, 2011). Determination of TIBC of the plasma can give a direct measurement of transferrin (Tsung et al., 1975), so the elevation of transferrin in response to gamma irradiation may reflect an increase in TIBC. In the present study administration of EA before and after $\gamma$-irradiation ameliorated serum iron. As it is a polyphenol compound (carrying four $\mathrm{OH}$ groups) it could scavenge iron raised by irradiation. EA at dose of $15 \mathrm{mg} / \mathrm{kg}$ returned serum iron and TIBC near to normal levels in myocardial infracted rats (Kannan et al., 2012). Moreover, supplementation of irradiated rats with ZA ameliorated the changes in serum iron, TIBC and transferrin disturbed by $\gamma$-irradiation. Similar results was obtained by Kandaz et al. (2009) who found that the increase in iron level after $\gamma$-irradiation was reduced by zinc sulphate administration. Accordingly, it was suggested that an increase in zinc-iron ratio in some organs may confer protection from iron catalysed free radicals-induced damage (Sorenson, 1989).

In addition, $\gamma$-irradiation (6.5Gy) led to an increase in hepatic and renal LPO and MTs levels, in parallel with depletion in hepatic and renal SOD and GSH. The decreased antioxidant status in irradiated rats might be due to the increased utilization of these antioxidants to counteract the ROS generated by irradiation (Oidovsambuu et al., 2013). Ping et al. (2012) showed that irradiation markedly decreased activities of SOD. GSH decrease upon radiation might be due to the oxidation of sulfhydryl group and diminished activity of glutathione reductase (Sarkar et al., 1998) or due to the deficiency of NADPH which is necessary to change oxidized glutathione to its reduced form (Said et al., 2005). MTs are small, cysteine-rich zinc binding proteins that are powerful antioxidants (Chung et al., 2006). Induction of MTs by irradiation appears to be due to an increased synthesis of liver MTs (Goossens, 2011). On the other hand, LPO has been suggested as one of the molecular mechanisms involved in radiation-induced toxicity (Adaramoye et al., 2008). Bhatia and Jain (2004), observed a significant depletion in the antioxidant system, and an increase in lipid peroxides after $\gamma$-radiation exposure. According to Mansour and El-Kabany (2009), the generation of lipid peroxide in the rat's liver and kidney might be due to the free radical attacked cell membrane phospholipids and circulating lipids.

Egypt. J. Rad. Sci. Applic., Vol. 26, No. 1-2 (2013) 
The co-administration of EA and ZA pre and post irradiation in the present study modulated the hepatic and renal oxidative stress.Thresiamma et al., (1998) stated that liver SOD increased upon EA supplementation compared with the irradiated ones. Also, EA treatment significantly induced total thiol and glutathione levels, and enhanced MT protein biosynthesis through selectively up-regulation of MT-mRNA expression (Gamal-Eldeen, 1997). EA being a phenolic compound carrying $4 \mathrm{OH}$ groups might have exerted antioxidantsparing action by scavenging free radicals (Michael, 2011). In addition, EA inhibits peroxidation of lipids thereby preserving the structural integrity of the cell membrane. Lee et al. (2010) indicated that EA inhibited NADPH oxidaseinduced overproduction of superoxide, enhancing cellular antioxidant defences. On the other hand, ZA has superoxide-scavenging effect produced by NADH oxidation (Amara et al., 2008). Moreover, the activity of $\mathrm{Cu} / \mathrm{Zn}$-SOD was increased with increasing organic Zn supplementation (Bun et al., 2011). It has been shown that zinc ions can elevate the glutathione level in cultured cells (Seagrave et al., 1983). The observed antioxidant effect of ZA may be related to its indirect anti-cytotoxic and anti-nitrosative effects and the ability of protecting thiol-dependent antioxidant proteins from oxidative damage (Turut $e t$ al., 2009). Raymond et al. (2010) observed that, elevated intracellular zinc content caused MT gene expression which result in increased MTs production and increased monocytes resistance to apoptosis. Expression of MTs genes in association with changes in zinc metabolism may represent a common host response to inflamation which may be due to gamma irradiation. Shaheen and el-Fattah (1995) reported that, Zn deficiency caused increased LPO and that this was overcome by $\mathrm{Zn}$ supplementation as $\mathrm{Zn}$ promote cell integrity. Treatment with ZA $(50 \mathrm{mg} / \mathrm{kg})$ in ischemia reperfusion model had equal MDA levels when compared with sham group (Ozdemir and Inanc, 2005).

In the present work, concerning trace elements in liver tissues, whole body $\gamma$-irradiation (6.5Gy) caused a decrease in $\mathrm{Zn}, \mathrm{Mg} \& \mathrm{Mn}$ concentrations and an increase in $\mathrm{Fe} \& \mathrm{Ca}$ levels. While in kidney tissues, there was a significant increase in $\mathrm{Ca}$ and $\mathrm{Mn}$ levels when compared with the control group. This finding was in agreement with Abdou et al. (2010) who proposed that, enhancement of calcium influx in the presence of oxygen was related to accumulation of ROS. The decreased $\mathrm{Zn}$ concentrations after irradiation Egypt. J. Rad. Sci. Applic., Vol. 26, No. 1-2 (2013) 
indicated enhanced consumption of this antioxidant element and/or antioxidant enzymes as a counterbalance to the effects of oxidants; this might be due to de novo synthesis of $\mathrm{Cu} / \mathrm{Zn}$-SODs and catalase which prevent the formation of $\mathrm{O}_{2}$ and hydroxyl radical associated with irradiation (Fee and Valentine, 1977). According to Hampton and Mayerson (1950), the kidney is capable of forming ferritin from iron released from haemoglobin. While in liver the oxidative stress induced by irradiation causes damage resulting in ferritin degeneration and increase in the intracellular free iron levels (Atkinson et al., 2005) and this explains why radiation increase the level of iron in liver but not in kidney. The disturbances in calcium and magnesium metabolism might be due to the insufficient renal function after irradiation (Kotb et al., 1990).

Supplementation of EA with ZA to the irradiated rats showed a synergistic ameliorative effect in almost tested trace elements of liver and kidney tissues. Kandaz et al. (2009) stated that, radiation caused elevation of Fe \&Ca level while upon treatment of irradiated rats with zinc sulphatethe elevated iron level start to decrease. On the other hand, Devipriya et al. (2007) reported that EA could normalize $\mathrm{Zn}$ levels during alcohol-induced toxicity in experimental rats. In addition, EA may have modulator effects on $\mathrm{Cu}$ and $\mathrm{Zn}$ levels in obstructive jaundice (Gumus et al., 2011). EA by its effective antioxidant property might have decreased the utility of zinc thioniens and other $\mathrm{Zn}$-containing enzymes like SOD and matrix metalloproteinases and thus maintained the levels of $\mathrm{Zn}$ as recorded in this study. EA plays an important role in the reduction of intracellular calcium (Gamal-Eldeen, 1997).In a study conducted to evaluates the potential of EA as an enhancer of radiation-induced apoptosis in cancer cells; they found that EA and radiation increased intracellular calcium levels of cancer cells (Bhosle et al., 2010).

In conclusion, we have demonstrated that, EA and/ or ZA may protect against the damage produced by radiation by the up-regulation of the antioxidant status and by ameliorating the alterations in some biochemical parameters as well as some trace elements. Therefore, these results should contribute to future studies that will examine the ability of EA and ZA to limit radiation toxicity and free radical pathologies in such cases of radiotherapy and radiation workers. 


\section{References}

Abdou, M. I., Shaban, H. A. and El Gohary, M. I. (2010) Changes in serum zinc, copper and ceruloplasmin levels of whole body gamma irradiated rats. Tenth Radiation Physics \& Protection Conference. 27-30 Nov 2010, Nasr CityCairo, Egypt.

Adaramoye, O., Ogungbenro, B., Anyaegbu, O. and Fafunso, M. (2008) Protective effects of extracts of Vernonia amygdalina, Hibiscus sabdariffa and vitamin C against radiation-induced liver damage in rats. J. Radiat. Res., 49, 123.

Agrawal, A., Chandra, D. and Kale, R. K. (2001) Radiation induced oxidative stress: II studies in liver as a distant organ of tumor bearing mice. Mol. Cell Biochem., 224, 9.

Amara, S., Abdelmelek, H., Garrel, C., Guiraud, P., Douki, T., Ravanat, J. L., Favier, A., Sakly, M. and Ben Rhouma, K. $(2 \cdots \wedge)$ Preventive effect of zinc against cadmium-induced oxidative stress in the rat testis. J. Reprod. Dev., 54, 129.

Atkinson, M. J., Spanner, M. T., Rosemann, M., Linzner, U., Muller, W. A. and Gossner, W. (2005) Intracellular sequestration of 223Ra by the iron-storage protein ferritin. Radiat. Res., 164, 230.

Bhatia, A. L. and Jain, M. (2004) Spinacia oleracea L. protects against gamma radiations: a study on glutathione and lipid peroxidation in mouse liver. Phytomedicine., 11, 607.

Bhosle, S. M., Ahire, V. R., Henry, M. S., Thakur, V. S., Huilgol, N. G. and Mishra, K. P. (2010) Augmentation of radiation-induced apoptosis by ellagic acid. Cancer Invest., 28, 323.

Bun, S. D., Guo, Y .M., Guo, F. C., Ji, F. J. and Cao, H. (2011) Influence of organic zinc supplementation on the antioxidant status and immune responses of broilers challenged with Eimeria tenella. Poult Sci., 90, 1220.

Chung, M. J., Hogstrand, C. and Lee, S. J. (2006) Cytotoxicity of nitric oxide is alleviated by zinc-mediated expression of antioxidant genes. Exp. Biol. Med., 231, 1555.

Devipriya, N., Sudheer, A. R. and Menon, V. P. (2007) Dose-response effect of ellagic acid on circulatory antioxidants and lipids during alcohol-induced toxicity in experimental rats. Fundam Clin. Pharmacol., 21, 621.

Dreux, C. (1977) Selected method. Analysis of human serum: assay of iron II. method using bathophenanthroline Se-Iron II (bathophenanthroline). Ann. Biol. Clin., 35,3, 275.

Ellman, G. L. (1959) Tissue sulfhydryl groups. Arch. Biochem. Biophys., 82, 70.

Fee, J. A. and Valentine, J. S. (1977) Chemical and physical properties of superoxide. In superoxide and superoxide dismutase (Michelson, A. M., McCord, J. M. and Fridovich, I.). pp. 19-60, Academic Press, New York.

Egypt. J. Rad. Sci. Applic., Vol. 26, No. 1-2 (2013) 
Gamal-Eldeen, A. M. (1997) Antioxidant mechanisms of ellagic acid with special focussing on metallothionein. Master thesis, cairo university.

Goossens, L. (2011) Effects of gamma-ray-induced free radicals on the metal content and amino acid composition of human metallothionein-1. J. Biosci., 36, 235.

Gumus, M., Yuksel, H., Evliyaoglu, O., Kapan, M ‘.Boyuk, A., Onder, A. and Aldemir, M. (2011) Effects of ellagic acid on copper, zinc, and biochemical values in serum and liver of experimental cholestatic rats. Biol. Trace. Elem. Res., 143, 386.

Guney, Y., Bukan, N., Dizman, A., Hicsonmez, A. and Bilgihan, A. (2004) Effects of two different high doses of irradiation on antioxidant system in the liver of guinea pigs. Eksp. Onkol., 26, 71.

Hampton, J. K., Jr. and Mayerson, H. S. (1950) Hemoglobin iron as a stimulus for the production of ferritin bythe kidney. Am. J. Physiol., 160, 1.

Kaczmarska, M., Kopyscianska, Z., Fornal, M., Grodzicki, T., Matlak, K., Korecki, J. and Burda, K. (2011) Effects of low doses of gamma rays on the stability of normal and diabetic erythrocyte. Acta. Biochim. Pol., 58, 489.

Kandaz, M., Ertekin, M. V., Erdemci, B., Kızltunç, A., Koçer, I., Özmen, H. K., Aktan, M. L. and Beșe, A. V. (2009) The effects of zinc sulfate on the levels of some elements and oxidative stress occurring in lenses of rats exposed to total cranium radiotherapy. EAJM., 41, 110.

Kannan, M. M., Quine, S. D. and Sangeetha, T. (2012) Protective efficacy of ellagic acid on glycoproteins, hematological parameters, biochemical changes, and electrolytes in myocardial infarcted rats. J. Biochem. Mol. Toxicol., 26, 270.

Kingston, H. M. and Jassei, L. B. (1988) Introduction to microwave sample preparation. ACS, Washington. DC.

Kotb, M. A., El-Khatib, A. M., Morsey, A. A., Ramadan, M. I. A. and El-Bassiouni, E. A. (1990) Changes in mineral elements tissues of mice following neutron irradiation. Isotopenpaxis., 26, 297.

Lee, W. J., Ou, H. C., Hsu, W. C., Chou, M. M., Tseng, J. J., Hsu, S. L., Tsai, K. L. and Sheu, W. H. (2010) Ellagic acid inhibits oxidized LDL-mediated LOX-1 expression, ROS generation, and inflammation in human endothelial cells. $J$. Vasc. Surg., 52, 1290.

Lowenthal, G. C. and Airey, P. L. (1997) Practical applications of radioactivity and nuclear reactions. Cambridge: Cambridge University Press.

Maiti, S., Meistrich, M. L., Wilson, G., Shetty, G., Marcelli, M., McPhaul, M. J., Morris, P. L. and Wilkinson, M. F. (2001) Irradiation selectively inhibits expression from the androgen-dependent Pem homeobox gene promoter in sertoli cells. Endocrinology, 142, 1567.

Mansour, S. Z. and El-Kabany, H. (2009) Effects of Fructus Piperis Longi extract on fibrotic liver of gamma-irradiated rats. Chin. Med., 4, 2.

Egypt. J. Rad. Sci. Applic., Vol. 26, No. 1-2 (2013) 
Maret, W. (2006) Zinc coordination environments in proteins as redox sensors and signal transducers. Antioxid. Redox. Signal., 8, 1419.

Michael, M. I. (2011) Beneficial use of continuous administration of Crataegus oxycantha in irradiated male albino rats. J. Rad. Res. Appl. Sci., 4, 301.

Minami, M. and Yoshikawa, H. (1979) A simplified assay method of superoxide dismutase activity for clinical use. Clin. Chim. Acta., 92, 337.

Nassar, O. M. (2011) Assessment of nutritional status of radiological technicians at Minufiya governorate, Egypt. Nutr. Food Sci., 41, 344.

Oidovsambuu, S., Kim, C. Y., Kang, K., Dulamjav, B., Jigjidsuren, T. and Nho, C. W. (2013) Protective effect of Paeonia anomala extracts and constituents against tert-butylhydroperoxide-induced oxidative stress in HepG2 cells. Planta Med., 79, 116.

Onosaka, S. and Cherian, M. G. (1982) The induced synthesis of metallothionein in various tissues of rats in response to metals. II. Influence of zinc status and specific effect on pancreatic metallothionein. Toxicology, 23, 11.

Ozdemir, G. and Inanc, F. (2005) Zincmay protect remote ocular injury caused by intestinal ischemia reperfusion in rats. TohokuJ. Exp. Med., 206, 247.

Özkaya, A., Çelik, S., Yuce, A., Şahin, Z. and YILMAZ, Ö. (2010) The effects of ellagic acid on some biochemical parameters in the liverof rats against oxidative stress induced by aluminum. Kafkas Univ. Vet. Fak. Derg., 16, 823.

Ozkaya, M. O., Naziroglu, M., Barak, C. and Berkkanoglu, M. (2011) Effects of multivitamin/mineral supplementation on trace element levels in serum and follicular fluid of women undergoing in vitro fertilization (IVF). Biol. Trace. Elem. Res., 139, 1.

Pari, L. and Sivasankari, R. (2008) Effect of ellagic acid on cyclosporine A-induced oxidative damage in the liver of rats. Fundam. Clin. Pharmacol., 22, 395.

Piccardi, G., Nyssen, M. and Dorche, J. (1972) Determination of iron and the total capacity for binding in human serum by a method without deproteinization. Clin. Chim. Acta, 40, 219.

Ping, X., Junqing, J., Junfeng, J. and Enjin, J. (2012) Radioprotective effects of troxerutin against gamma irradiation in mice liver. Int. J. Radiat. Biol., 88, 607.

Raymond, A. D., Gekonge, B., Giri,M. S., Hancock, A., Papasavvas, E., Chehimi, J., Kossenkov, A. V., Nicols, C., Yousef, M., Mounzer, K., Shull, J., Kostman, J., Showe, L. and Montaner, L. J. (2010) Increased metallothionein gene expression, zinc, and zinc-dependent resistance to apoptosis in circulating monocytes during HIV viremia. J. Leukoc. Biol., 88, 589.

Said, U. Z., Rezk, R. G. and Saada, H. N. (2005) Role of calcium pantothenate in recovery of radiation induced injury to mammalian organs. Egypt J. Rad. Sci. Applic., 18, 17.

Egypt. J. Rad. Sci. Applic., Vol. 26, No. 1-2 (2013) 
Sarkar, S., Yadav, P. and Bhatnagar, D. (1998) Lipid peroxidative damage on cadmium exposure and alterations in antioxidant system in rat erythrocytes: a study with relation to time. Biometals, 11, 153.

Seagrave, J., Tobey, R. A. and Hildebrand, C. E. (1983) Zinc effects on glutathione metabolism relationship to zinc-induced protection from alkylating agents. Biochem. Pharmacol., 32, 3017.

Shaheen, A. A. and el-Fattah, A. A. (1995) Effect of dietary zinc on lipid peroxidation, glutathione, protein thiols levels and superoxide dismutase activity in rat tissues. Int. J. Biochem. Cell. Biol. 27, 89.

Sorenson, J. R. (1989) Copper complexes offer a physiologicalapproach to treatment of chronic diseases. Prog. Med. Chem., 26, 437.

Sorenson, J. R. (2002) $\mathrm{Cu}, \mathrm{Fe}, \mathrm{Mn}$, and $\mathrm{Zn}$ chelates offer a medicinal chemistry approach to overcoming radiation injury. Curr. Med. Chem., 9, 639.

Thresiamma, K. C., George, J. and Kuttan, R. (1998): Protective effect of curcumin, ellagic acid and bixin on radiation induced genotoxicity. J. Exp. Clin. Cancer Res., 17, 431.

Tsung, S. H., Rosenthal, W. A. and Milewski, K. A. (1975) Immunological measurement of transferrin compared with chemical measurement of total iron-binding capacity. Clin. Chem., 21, 1063.

Turut, H., Kurutas, E. B., Bulbuloglu, E., Yasim, A., Ozkaya, M., Onder, A. and Imrek, S. S. (2009) Zinc aspartate alleviates lung injury induced by intestinal ischemia-reperfusion in rats. J. Surg. Res., 151, 62.

Wang, A., Liu, Z., Wang, H., Li, Y., Liao, S. and Wang, Y. (2009) Determination of ellagic acid compounds in Euscaphis japonica by using UPLC. China J. Chinese Materia Med., 34, 3235.

Yoshioka, T., Kawada, K., Shimada, T. and Mori, M. (1979) Lipid peroxidation in maternal and cord blood and protective mechanism against activated-oxygen toxicity in the blood. Am. J. Obstet. Gynecol., 135, 372.

(Received: 09/12/2013;

accepted: 31/12/2013)

Egypt. J. Rad. Sci. Applic., Vol. 26, No. 1-2 (2013) 


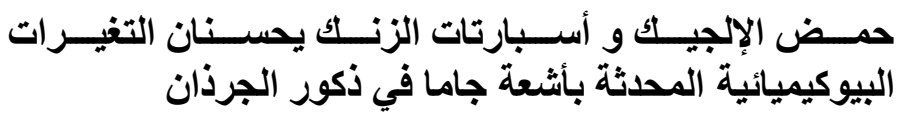

علا سيد علي و أحمد شفيق ندا* و دعاء محمد عبد اللطيف و مي حمدي مكاوي*

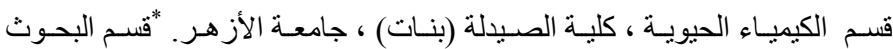

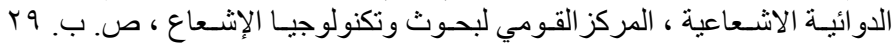

مدينة نصر ، القاهرة ، مصر.

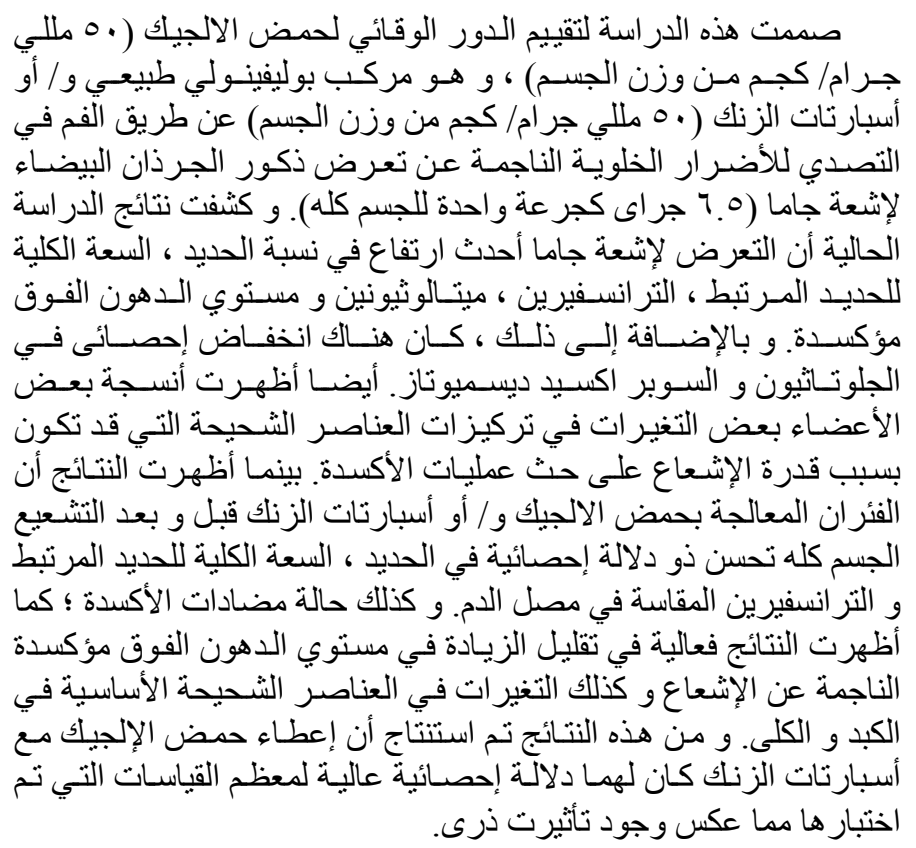

Egypt. J. Rad. Sci. Applic., Vol. 26, No. 1-2 (2013) 